\title{
PENGARUH PENGAWASAN DAN PEMBINAAN TERHADAP PENINGKATAN KINERJA PEGAWAI BADAN PENDAPATAN DAERAH PROVINSI SULAWESI SELATAN
}

\author{
Enny Agustina Baharuddin ${ }^{1}$, Abdul Mahsyar ${ }^{2}$, Nuryanti Mustari $^{3}$ \\ Universitas Muhammadiyah Makassar \\ e-mail: enny.ashari170870@gmail.com
}

\begin{abstract}
Abstrak
Pendayagunaan aparatur pemerintah diarahkan untuk menciptakan aparatur yang lebih efisien, efektif, bersih dan berwibawa serta mampu melaksanakan seluruh tugas umum pemerintahan dan pembangunan dengan sebaikbaiknya dengan dilandasi semangat dan sikap pengabdian pada masyarakat, bangsa dan negara. Dinas Pendapatan Daerah Provinsi Sulawesi Selatan masih sering terlihat adanya pegawai yang melaksanakan tugas kurang sesuai dengan standar kinerja yang diharapkan organisasi, baik terhadap penggunaan waktu kerja maupun terhadap prosedur-prosedur kerja yang ada, seperti datang terlambat dan pulang lebih cepat serta menyimpn dari prosedur-prosedur kerja yang ada. Data yang didapatkan di lapangan dianalisis secara deskriptif dan didukung oleh data kuantitatif, menggunakan nilai persentase dan analisis rata-rata. Hasil penelitian yaitu 1) Pengawasan preventif di Badan Pendapatan Daerah Provinsi Sulawesi Selatan dengan indicator pada disiplin kerja oleh pegawai, berjalan baik, yaitu umumnya menggunakan jam kerja sesuai ketentuan yang berlaku. Terdapat usaha-usaha yang cukup signifikan dari pegawai negeri untuk mentaati jam kerjanya; 2) Tindakan pengawasan represif, maka berbagai tindakan yang dilakukan untuk mendisiplinkan pegawai dalam mentaati prosedur dan mekanisme kerja adalah meminta pegawai yang bersangkutan untuk menghadap langsung ke atasan, dan memberikan teguran peringatan dan bilamana itu belum ditaati, maka dilimpahkan ke pejabat Pembina kepegawaian melalui identifikasi masalah pada Badan Pendapatan Daerah Provinsi Sulawesi Selatan untuk melakukan evaluasi laporan disiplin pegawai.
\end{abstract}

Kata Kunci : pegawai, kinerja, pengawasan, pembinaan

\begin{abstract}
The utilization of government apparatus is directed at creating more efficient, effective, clean and authoritative apparatuses and capable of carrying out all general tasks of government and development as well as possible based on the spirit and attitude of service to the community, nation and state. The Regional Revenue Service of South Sulawesi Province is still often seen that there are employees who carry out tasks that are not in accordance with the performance standards expected by the organization, both for the use of working time and for existing work procedures, such as arriving late and leaving early and saving from procedures. existing work. The data obtained in the field were analyzed descriptively and supported by quantitative data, using percentage values and average analysis. The results of the study were 1) Preventive supervision at the Regional Revenue Agency of South Sulawesi Province with indicators on work discipline by employees, went well, which generally used working hours according to applicable regulations. There are significant efforts by civil servants to comply with their working hours; 2) Repressive supervisory actions, various actions taken to discipline employees in complying with work procedures and mechanisms are asking the employee concerned to appear directly to the supervisor, and give a warning warning and if it has not been complied with, then delegated to the staffing officer through identification of problems at the Regional Revenue Agency of South Sulawesi Province to evaluate employee discipline reports.
\end{abstract}

Keywords: employees, performance, supervision, coaching

\section{PENDAHULUAN}

Pendayagunaan aparatur pemerintah diarahkan untuk menciptakan aparatur yang lebih efisien, efektif, bersih dan berwibawa serta mampu melaksanakan seluruh tugas umum pemerintahan dan pembangunan dengan sebaik-baiknya dengan dilandasi semangat dan 
sikap pengabdian pada masyarakat, bangsa dan negara. Dalam hubungan ini kemampuan aparatur pemerintah untuk merencanakan, melaksanakan, mengawasi, mengendalikan pembangunan perlu ditingkatkan.

Fungsi pengawasan dalam pendayagunaan birokrasi pemerintahan adalah merupakan bagian penting dari manajemen dan administrasi pemerintahan itu sendiri, guna menjamin kesesuaian dan ketepatan pelaksanaan tugas-tugas dari orang-orang yang terlibat di dalamnya, dalam hal ini menjamin kedisiplinan kerja mereka agar dapat berjalan sesuai dengan rencana dan struktur organisasi yang ada. Oleh sebab itu fungsi pengawasan intern dalam konteks manajemen kepegawaian di Indonesia, dimasukkan sebagai fungsi pengendalian terhadap penggunaan dan pemanfaatan sumber daya, proses kerja dan hasil kerja itu sendiri.

Dinas Pendapatan Daerah Provinsi Sulawesi Selatan masih sering terlihat adanya pegawai yang melaksanakan tugas kurang sesuai dengan standar kinerja yang diharapkan organisasi, baik terhadap penggunaan waktu kerja maupun terhadap prosedur-prosedur kerja yang ada, seperti datang terlambat dan pulang lebih cepat serta menyimpan dari prosedur-prosedur kerja yang ada. Oleh sebab itu pengawasan, terutama pengawasan intern yang merupakan pengawasan oleh masingmasing atasan langsung terhadap bawahannya merupakan suatu kebutuhan yang telah ditetapkan.

Terdapatnya perbedaan karakter dan prilaku manusia dalam bekerja juga menyebabkan terdapatnya beragam motif dan motivasi dalam mencapai tujuan dengan baik. Ada pegawai yang memerlukan pengawasan dan pengendalian baru dapat bekerja dengan efektif, namun juga terdapat pegawai yang memiliki integritas yang baik dan tidak perlu diawasi dengan ketat, namun cukup memberikan penjelasan mengenai tugas dan tanggungjawabnya. Hal tersebut juga berkaitan dengan kultur masyarakat itu sendiri, yang hanya takut pada apa yang dihadapannya, namun tidak taat pada aturan dan norma yang berlaku. Oleh sebab itu proses pengawasan yang dimaksudkan untuk mengarahkan, mengendalikan agar seluruh tujuan dapat tercapai sesuai program, rencana dan tata kerja yang telah ditetapkan.
Sorotan terhadap masih rendahnya sebagian kinerja pegawai dapat dikatakan merupakan penomena tersendiri dalam aktivitas birokrasi pemerintahan di Indonesia, sebab jumlah pegawai negeri sipil yang bekerja pada sektor birokrasi pemerintah cukup besar, sehingga distribusi tugas dan jabatan kadang-kadang kurang proporsional, sehingga ada sebagian pegawai yang kelihatan kurang berfungsi dan cenderung menggunakan waktu kerja seenaknya saja tanpa mengindahkan mekanisme dan prosedur yang telah digariskan oleh institusinya, sebagaimana sering terlihat adanya sebagian pegawai negeri yang datang terlambat dan pulang lebih cepat dari jam kerja yang ditetapkan, bahkan kadang-kadang ditemukan adanya pegawai yang berkeliaran di tempat-tempat umum pada jam kerja.

Disinyalir bahwa rendahnya kinerja sebagian pegawai merupakan implikasi dari lemahnya pengawasan yang dilakukan oleh masing-masing atasan dalam organisasi Dinas Pendapatan Daerah Provinsi Sulawesi Selatan, bahkan tindak lanjut dari suatu pengawasan jarang sekali dilaksanakan, seperti memberi teguran atau sanksi hukuman kepada para pegawai yang dianggap menyalahi dari prosedur dan mekanisme kerja yang ada.

\section{TINJAUAN PUSTAKA}

\section{Pengertian Pengawasan}

Menurut Gie (1972 : 32) mengemukakan bahwa Pengawasan adalah keseluruhan aktivitas dalam mengawali, memeriksa dan mengendalikan setiap kegiatan agar berlangsung sesuai dengan rencana. Selanjutnya Soekarno (1986 : 48) yang mengemukakan bahwa pengawasan adalah suatu proses yang menentukan tentang apa yang harus dikerjakan, cara apa yang harus ditempuh sejalan dengan rencana".

Selanjutnya Sarwoto ( 2003 : 98) mengemukakan bahwa pengawasan adalah penilaian dan koreksi atas pelaksanaan pekerjaan yang dilakukan oleh para bawahan yaitu dengan maksud untuk mendapatkan keyakinan atau menjamin bahwa tujuan-tujuan perusahaan seuai dengan rencana yang digunakan untuk mencapainya.

Koontz \& O'Donnel (Handayaningrat, 1992), mengemukakan bahwa pengawasan memiliki hubungan yang erat dengan 
perencanaan (planning), ini berarti erat pula kaitannya dengan kebijaksanaan (objektive), tujuan (objektive), pengorganisasian (organizing).

Berdasar pada batasan pengertian tersebut di atas dapatlah ditarik suatu kesimpulan bahwa pengawasan adalah suatu usaha pimpinan yang menginginkan agar setiap pekerjaan dilaksanakan sebagaimana mestinya. Demikian pula bahwa pengawasan erat sekali hubungannya dengan perncanaan sehingga dapat dikatakan bahwa perencanaan dan pengawasan adalah ibarat dua sisi mata uang, artinya bahwa rencana tanpa pengawasan akan menimbulkan kemungkinan penyimpangan dengan tanpa ada alat untuk mencegahnya. Tegasnya bahwa pengawasan merupakan suatu usaha penertiban untuk menjamin terlaksananya segala ketentuan peraturan perundang-undangan yang berlaku atau dengan kata lain bahwa pengawasan adalah suatu usaha untuk menjaga supaya segala tindakan atau kegiatan sesuai dengan apa yang diharapkan.

\section{Pembinaan Disiplin Pegawai}

Menurut pendapat Bedjo Siswanto (2007 : 278) dalam buku, Manajemen Tenaga Kerja mengemukakan pengertian disiplin yaitu suatu sikap yang menghormati, menghargai, patuh dan taat terhadap peraturan-peraturan yang berlaku, baik terulis maupun tidak tertulis serta sanggup menjalankannya dan tidak menolak untuk menerima sanksi apabila ia melanggar tugas dan wewenang yang diberikan padanya.

Selanjutnya Soegeng (2002: 23) mengemukakan bahwa suatu kondisi yang tercipta dan terbentuk melalui proses dan serangkaian perilaku yang menunjukkan nilainilai ketaatan, kepatuhan, kesetiaan, keteraturan dan atau ketertiban.

Selain itu pula sejalan dengan tugas dan kewajiban sebagai unsur aparatur negara, abdi negara dan abdi masyarakat dapat memberikan pelayanan kepada masyarakat dengan baik, dilandasi semangat pengabdian, etika dan moral yang tinggi serta berperilaku yang didasari kualitas spiritual yang mantap.

Sedangkan menurut Moenir (2003: 181) pendisiplinan atau disiplinisasi, ialah usaha yang dilakukan untuk menciptakan keadaan disuatu lingkungan kerja yang tertib, berdayaguna dan berhasilguna melalui sistem pengaturan yang tepat.
Dengan mengambil asumsi-asumsi sederhana tersebut di atas, jelaslah bahwa orang-orang atau aparatur yang berada pada lingkup organisasi pemerintah apabila sudah dapat berlaku baik sebagaimana kriteria Kaho tersebut, maka jelas memberikan indikasi pengertian bahwa aparat yang bersangkutan telah memiliki prestasi kerja.

Fenomena yang terjadi selama ini, terutama sorotan berbagai pihak adalah tumbuhnya ketidak disiplinan birokrasi pemerintahan di Indonesia, seperti tumbuh suburnya korupsi, kolusi dan nepotisme atau lebih populer disebut KKN, adalah merupakan fenomena yang tumbuh dan berkembang di tengah masyarakat Indonesia. Bahkan salah satu Majalah terkemuka dunia "Times" pernah melangsir bahwa Indonesia merupakan salah satu negara paling banyak koruptornya, baik dimasa pemerintahan Orde Lama, Orde Baru maupun di masa reformasi ini.

Indikator terjadinya Korupsi, Kolusi dan Nepotisme dapat dilihat pada penyalahgunaan uang negara, penyelewengan pajak oleh perusahaan-perusahaan ataupun perorangan, adanya praktek-praktek penyuapan dalam berbagai dimensi kegiatan masyarakat dalam memperoleh kemudahan pelayanan, bahkan keinginan untuk mengembangkan kariernya dengan cepat dari para pegawai pemerintah, praktek mengutamakan kepentingan pribadi, keluarga ataupun kelompok. Praktek-praktek KKN tersebut tidak hanya merugikan dalam kehidupan berbangsa dan bernegara, akan tetapi telah meluluh lantakkan sendi-sendi kehidupan bermasyarakat secara makro. Hal ini terbukti dengan terjadinya krisis multi dimensional sebagai dampak dari rendahnya kepercayaan dunia Internasional terhadap penyelenggaraan pemerintahan yang bersih dan berwibawa. Keengganan lembaga dana moneter Internasional untuk mengucurkan dana bantuannya merupakan implikasi dari keraguannya terhadap masih merajalelanya korupsi, kolusi dan nepotisme. Kalaupun bersedia memberikan bantuan, maka setumpuk persyaratan harus dipenuhi, termasuk memberantas para koruptor kelas kakap, yang cenderung sangat sulit dilakukan.

Upaya menciptakan pemerintahan yang bersih dan berwibawa, telah dimulai dengan lahirnya Undang-Undang No. 28 Tahun 1999 tentang penyelenggaraan negara yang bersih dan bebas KKN, dan kemudian diikuti dengan 
pembentukan Komisi Penyelidik Kekayaan Penyelenggara Negara (KPKPN) serta lahirnya undang-undang pemberantasan Korupsi Kolusi dan Nepotisme.

\section{Konsep Kinerja}

Kinerja yang dalam Bahasa Inggris disebut "performance" yang memiliki arti penampilan atau prestasi. Dalam sistem menagament by objective, Murphy \& Cleveland (2005: 19) mendefenisikan "performance" sebagai countable outcomes, yang berarti hasil yang dicapai yang memiliki makna dapat dipertanggung jawabkan.

Kinerja (perfomance) dalam kaitannya dengan suatu organisasi dapat diartikan sebagai hasil atau prestasi yang dicapai oleh sebuah organisasi. Untuk mengetahui prestasi sebuah organisasi tentu memerlukan ukuran atau kriteria sebagai indikator prestasi (keberhasilan) yang dicapai.

Gibson dkk (2006) mengemukakan bahwa kinerja atau prestasi ditentukan oleh interaksi kemampuan dan motivasi dengan persamaan: Prestasi $=$ kemampuan $\mathrm{X}$ Motivasi. Demikian pula pendapat Duncan dalam Indrawijaya (1996) yang mengemukakan bahwa prestasi (P) adalah fungsi perkalian motivasi (m) dengan kemampuan $(\mathrm{k})$ atau dalam persamaan matematikanya adalah $\mathrm{P}=\mathrm{f}(\mathrm{MxK})$.

August W. Smith dalam Sedarmayanti (2001 : 50 ) menyatakan bahwa perfomance atau kinerja adalah "......out put drive from process, human or otherwise", jadi dikatakannya bahwa kinerja merupakan hasil atau keluaran dari suatu proses.

\section{METODE}

Metode penelitian yang digunakan adalah metode deskriptif. Metode penelitian yang digunakan untuk meneliti status kelompok manusia, objek, situasi, serta kondisi suatu sistem pemikiran ataupun kelas peristiwa secara sistematis, faktual dan akurat tentang fakta-fakta serta hubungan fenomena yang diselidiki.

Populasi dalam penelitian ini adalah seluruh pegawai yang berstatus pegawai negeri sipil di bawah tugas Badan Pendapatan Daerah Provinsi Sulawesi Selatan, yang berjumlah 50 orang. Teknik sampling yang digunakan adalah total sampling atau sampel jenuh, yaitu seluruh populasi menjadi sampel penelitian.

Untuk memperoleh data-data yang dibutuhkan dalam penelitian ini digunakan beberapa metode yaitu Kuesioner, Wawancara, Observasi, Dokumentasi.

Data yang didapatkan di lapangan dianalisis secara deskriptif dan didukung oleh data kuantitatif, menggunakan nilai persentase dan analisis rata-rata. Untuk mengetahui tanggapan responden berdasarkan kelompok responden, data yang diperoleh diolah dalam bentuk persentase pada tabel frekuensi distribusi

\section{HASIL DAN PEMBAHASAN}

\section{Analisis Hasil Penelitian}

\section{a. Pengawasan intern preventif}

Dalam penelitian ini mengenai fungsi pengawasan preventif pengawasan preventif terhadap pegwai di jajaran Badan Pendapatan Daerah Provinsi Sulawesi Selatan, maka disoroti dalam dua hal yang merupakan indikator utama dalam penelitian ini, yaitu :

1) Pengawasan disiplin terhadap penggunaan jam kerja

Hasil penelitian menunjukkan bahwa penggunaan waktu kerja pegawai merupakan hal yang esensial yang menjadi ukuran dalam menilai kedisiplinan kerja pegawai. Sebab ketersediaan waktu kerja yang memadai oleh pegawai, maka memungkinkan untuk menyelesaikan pekerjaan sesuai dengan harapan dan keinginan organisasi.

Sebagaimana dikemukakan sebelumnya bahwa waktu kerja pegawai di Badan Pendapatan Daerah Provinsi Sulawesi Selatan adalah enam hari kerja yaitu senin sampai dengan Jumat, mulai jam $7.30 \mathrm{~s} / \mathrm{d} \quad 16.00$. Dalam arti bahwa rata-rata pegawai dapat memanfaatkan jam kerja sebanyak 8 jam perhari, hanya saja bahwa masalahnya penggunaan jam kerja pegawai umumnya efektif lima jam kerja, bahkan untuk pegawai yang tidak menduduki jabatan struktural atau fungsional di Kantor, mereka hanya rata-rata memiliki waktu kerja efektif 4 jam.

Tentang penelitian mengenai disiplin penggunaan waktu kerja pegawai, maka dilakukan terhadap beberapa indikator, diantaranya: 


\section{a) Disiplin jam masuk Kantor}

Hasil wawancara dengan Kepala Badan Pendapatan Daerah Provinsi Sulawesi Selatan, tentang upaya pembinaan bagi pegawai negeri sipil dalam penggunaan jam kerja secara optimal, maka dijelaskan sebagai berikut :

Saat ini di jajaran Pemerintah Daerah Provinsi Sulawesi Selatan telah diterapkan imbalan bayaran prestasi berupa Uang Tambahan Penghasilan (UTP). UTP ini dikaitkan dengan kemampuan pegawai untuk menggunakan jam kerja sesuai dengan ketentuan yang berlaku, di mana UTP dihitung berdasarkan kehadiran pegawai. Jadi pegawai yang terlambat atau terlalu cepat pulang, maka pada hari itu langsung dikurangi UTPnya, sehingga akumulasi penerimaan UTP bagi pegawai akan dihitung berdasarkan indikasi kehadirannya. Dasar pemberian UTP ini juga dijadikan acuan menilai kepatuhan pegawai menggunakan jam kerja di lingkugan kerjanya masing-masing.

Dari data yang diolah, maka dapat dilihat bahwa nilai rata-rata jawaban responden adalah sebesar 3,86 atau menunjuk pada kategori jawaban disiplin, hal ini sejalan dengan jawaban relatif responden pada angka persentase yang umumnya $(41,46 \%)$ mengatakan pegawai di Provinsi Sulawesi Selatan memiliki disiplin dalam penggunaan jam kerja masuk kantor. Meskipun sebenarnya masih ada penilaian responden yang melihat bahwa masih ada sebagian pegawai yang kurang disiplin dalam penggunaan masuk jam kerja, namun secara keseluruhan pegawai yang ada tersebut dinilai disiplin dalam penggunaan jam masuk kerja, yaitu jam 7.30 sesuai dengan ketentuan berlaku.

\section{b) Pegawai Berkeliaran di Luar}

Pada indikator penelitian ini diteliti mengenai ketaatan pegawai dalam mematuhi ketentuan jam pulang kantor oleh pegawai negeri sipil di Kabupaten Provinsi Sulawesi Selatan, yaitu jam 15.30.

Berdasar data yang diolah, maka dapat dilihat bahwa dari 50 responden yang diteliti, maka diperoleh nilai rata-rata jawaban responden sebesar 4,04 atau menunjuk pada kategori jawaban jarang sekali, hal ini berarti bahwa menurut penilaian responden bahwa dilihat dari indikator pegawai yang berkeliaran pada jam kerja kantor, maka nampaknya pegawai dapat dikatapan disiplin dalam penggunaan jam kerja.

c) Efisiensi Penggunaan Jam Kerja

Yang diteliti pada sub variabel ini adalah tentang Tanggapan Responden mengenai efisiensi penggunaan jam kerja, dalam hal ini diteliti mengenai penilaian responden terhadap penggunaan secara menyeluruh pada penggunaan jam kerja pegawai. Dalam hal ini peneliti menanyakan apakah pegawai ada indikasi penggunaan jam kerja tidak efisien.

Dari data yang diolah, dapat dilihat bahwa nilai rata-rata jawaban responden dalam hal efisiensi penggunaan jam kerja pegawai secara keseluruhan, maka diperoleh rata-rata jawaban responden sebesar 4,14 atau menunjuk pada kategori jawaban jarang sekali, dalam arti jarang sekali dijumpai adanya indikasi penggunaan jam kerja yang tidak efisien.

\section{2) Disiplin pada Ketentuan Jam Pulang}

Masih adanya pegawai yang meninggalkan jam kantor sebelum waktunya, merupakan fenomena terhadap adanya pegawai yang belum mentaati penggunaan jam kerja secara menyeluruh. Harus diakui bahwa masih terdapatnya pegawai yang tidak memiliki intensitas kerja yang tinggi, karena job-job yang kurang jelas, tentu dapat membuat pegawai untuk berpikir segera meninggalkan kantor meskipun belum waktu yang ditentukan.

Pegawai Negeri Sipil (PNS) yang merupakan sumber daya aparatur adalah faktor penting dalam rangka mencapai suatu mekanisme kerja yang efisien dan efektif, sebab aparatur merupakan subyek dalam setiap aktifitas pemerintahan. Aparatur yang merupakan pelaku penggerak proses mekanisme dalam sistem pemerintahan, oleh sebab itu agar mekanisme pemerintah tersebut berjalan dengan sebaik-baiknya, yakni sesuai dengan yang diharapkan maka aparatur selaku subyek atau pelaku harus memiliki kemampuan yang relevan dengan kebutuhan tugas-tugasnya.

Meskipun ada tingkat kesadaran aparatur yang cukup memadai dalam menjalankan tugas-tugasnya, namun perlu disadari pula bahwa prilaku dan karakter manusia, kadangkadang dapat dengan mudah berubah, dan sangat dipengaruhi oleh kondisi dan kesempatan yang ada di depan matanya, 
misalnya mungkin tidak ada niat untuk bolos kerja namun karena melihat ada kesempatan dan peluang yang terbuka, maka hal itupun dapat saja dilakukan.

Disiplin pegawai pada penggunaan jam pulang, maka dilakukan penelitian pada beberapa indikator, yaitu:

a) Penggunaan Jam Pulang Sesuai Ketentuan Berdasar data yang diolah, maka dapat diperoleh rata-rata jawaban responden sebesar 4,08 atau menunjuk pada kategori jawaban sesuai, dalam arti bahwa menurut responden penggunaan jam pulang kantor oleh pegawai Badan Pendapatan Daerah Provinsi Sulawesi Selatan Provinsi Sulawesi Selatan adalah sesuai dengan ketentuan yang berlaku di Provinsi Sulawesi Selatan, dalam arti bahwa ada apresiasi memadai pegawai terhadap peraturan penggunaan jam kerja yang ada di Provinsi Sulawesi Selatan.

b) Dijumpai Unit Kerja Tertentu di Badan Pendapatan Daerah Provinsi Sulawesi Selatan Provinsi Sulawesi Selatan Sebagian Pegawainya Pulang Berdasar data yang diolah, maka dapat dilihat bahwa dari 50 responden yang diteliti, maka diperoleh rata-rata jawaban responden sebesar 4,14 atau menunjuk pada kategori jawaban jarang sekali, dalam arti bahwa jarang sekali dijumpai adanya pegawainya telah pulang pada saat masih jam kerja berlangsung.

c) Sengaja Menutup Identitas PNS Karena Meninggalkan Kantor pada Saat Kerja Masih Berlangsung. Dengan demikian sesuai data yang diolah, maka dari 50 responden yang diteliti, maka diperoleh rata-rata jawaban responden sebesar 4,08 atau menunjuk pada kategori jarang sekali, dalam arti bahwa menurut responden jarang sekali dijumpai pegawai yang sengaja menutup identitasnya karena keinginan bolos kerja.

Dari keterangan data tersebut dapat diketahui bahwa penilaian responden terhadap disiplin kerja pegawia dalam penggunaan jam kerja di Badan Pendapatan Daerah Provinsi Sulawesi Selatan maka umumnya pada ratarata jawaban 4, Ini berarti bahwa pegawai negeri sipil yang ada di Provinsi Sulawesi Selatan, khususnya pada jajaran birokrasi pemerintahan Badan Pendapatan Daerah
Provinsi Sulawesi Selatan secara menyeluruh dapat dinilai disiplin dalam penggunaan pada jam kerja pegawai. Dengan demikian menurut responden disiplin terhadap penggunaan jam kerja adalah berada pada kategori disiplin, dalam arti bahwa pada umumnya pegawai yang ada dapat memahami prosedur kerja yang telah ditetapkan.

Berdasarkan data yang diolah, maka dapat dilihat bahwa nilai rata-rata jawaban responden pada indikator peranan pengawasan preventif adalah 3,92 yang menunjuk pada bobot 4 atau kategori baik, dalam arti dalam hal melakukan tindakan preventif pada pelanggaran disiplin penggunaan jam kerja dinilai berperanan baik.

Sehubungan dengan informasi data yang diolah, maka pada dasarnya didukung fakta bahwa tingkat absensi pegawai yang melaksanakan tugas di Badan Pendapatan Daerah Provinsi Sulawesi Selatan ditunjukkan bahwa dari 51 pegawai yang ada selama tahun 2010, maka diperoleh catatan sebagai berikut :

a) Tingkat kehadiran pegawai di Kantor 90 $\%$.

b) Persentase keterlambatan pegawai masuk kantor hanya sekitar $10 \%$, dengan ratarata terlambat 20-30 menit dari waktu yang ditentukan.

c) Jumlah pegawai yang meninggalkan kantor pada jam kerja, hanya $0,5 \%$ dengan variasi alas an yang berbeda-beda, mulai yang berhubungan tugas maupun karena keinginan sendiri.

\section{3) Pengawasan represif penegakkan disiplin pegawai}

dalam

Para pegawai yang dianggap melakukan pelanggaran atau tidak melaksanakan tugas berdasarkan prosedur dan mekanisme kerja yang berlaku, maka tersedia tindakan represif sanksi administratif dan tindakan hukum pidana atau perdata.

Meskipun demikian sehubungan dengan peranan Satuan Kerja yang diberi kewenangan tugas dalam penegakkan disilin masing-masing penggunaan jam kerja pegawai di lingkungan Badan Pendapatan Daerah Provinsi Sulawesi Selatan Provinsi Sulawesi Selatan, maka tindakan-tindakan represif yang dilakukan adalah lebih berkaitan tindakan-tindakan pelaporan, dalam arti bahwa temuan-temuan pada pelanggaran penggunaan jam kerja pegawai belum bisa dilakukan eksekusi, dalam 
arti belum ada aturan mengenai tindakantindakan yang langsung dapat dilakukan oleh satuan kerja masing-masing terhadap pegawai negeri sipil itu sendiri. Apalagi bahwa antara struktur tugas Badan Pendapatan Daerah Provinsi Sulawesi Selatan dengan pegawai negeri sipil yang ada adalah merupakan bagian yang terintegrasi yang bekerja pada satu sistem yang sama dalam arti ada kewenangan yang jelas mengenai kedudukan atasan dalam penegakkan disiplin kerja pegawai.

Berdasar data yang diolah, maka diperoleh rata-rata jawaban responden sebesar 4,18 atau menunjuk pada kategori apresiatif, dalam arti bahwa menurut responden para pegawai negeri sipil yang ada di Badan Pendapatan Daerah Provinsi Sulawesi Selatan memiliki respek terhadap fungsi pengawasan dalam upaya penegakkan disiplin penggunaan jam kerja pegawai di Badan Pendapatan Daerah Provinsi Sulawesi Selatan.

Masih ada sebagian pegawai yang cenderung menggunakan waktu kerja seenaknya saja tanpa mengindahkan mekanisme dan prosedur yang telah digariskan oleh institusinya, maka banyak pegawai yang harus dipotong tunjangan lauk pauknya karena bolos kerja. Dari sumber data yang ada (Bagian Tata Usaha Sekretariat Badan Pendapatan Daerah Provinsi Sulawesi Selatan, pada tahun 2019, terdapat 9 orang pegawai yang tunjangan lauk pauknya dipotong sebanyak 8 hari, 6 orang pegawai dipotong 5 hari dan 2 orang 4 hari.

Lebih lanjut ditanyakan mengenai apakah bila dijumpai adanya pegawai yang melanggar ketentuan mengenai penggunaan jam kerja, dan telah melaporkan ke atasannya atau pembina kepegawaian Badan Pendapatan Daerah Provinsi Sulawesi Selatan, mendapatkan tanggapan atau tindak lanjut dari atasan pegawai bersangkutan.

Berdasar data yang diolah, maka dari 50 responden yang diteliti, maka diperoleh ratarata jawaban responden sebesar 4,16 atau menunjuk pada kategori jawaban baik, dalam arti bahwa menurut responden tindak lanjut terhadap laporan mengenai indisipliner pegawai dalam penggunaan jam kerja pegawai adalah baik, dalam arti bahwa selalu tanggapan yang positif berupa tindak lanjut, hal ini dilihat pada setiap adanya kasus pelanggaran disiplin jam kerja selalu disampaikan pada setiap upacara bendera dan apel pagi.
Dari keterangan data tersebut dapat diketahui bahwa penilaian responden terhadap apresiasi pegawai sanksi-sanksi disiplin kerja pegawai dalam penggunaan jam kerja di Badan Pendapatan Daerah Provinsi Sulawesi Selatan rata-rata baik $(4,00)$. Ini berarti bahwa pegawai negeri sipil yang ada di Badan Pendapatan Daerah Provinsi Sulawesi Selatan Provinsi Sulawesi Selatan, khususnya pada jajaran birokrasi pemerintahan Badan Pendapatan Daerah Provinsi Sulawesi Selatan secara menyeluruh dinilai responden memiliki apresiasi terhadap penegakkan disiplin kerja. Dengan demikian menurut responden apresdiasi pegawai terhadap sanksi disiplin terhadap penggunaan jam kerja adalah berada pada kategori baik, dalam arti bahwa pada umumnya pegawai yang ada dapat memahami akibat-akibat ketidak disiplinan dalam bekerja.

Upaya peningkatan disiplin kerja pegawai, pada dasarnya telah banyak diupayakan oleh pemerintah, bahkan dikeluarkannya Peraturan Pemerintah Nomor 53 Tahun 2010, tentang Peraturan Disiplin Pegawai Negeri Sipil, telah memuat hampir seluruh kewajiban dan larangan bagi seorang pegawai negeri sipil, baik dalam lingkungan internal pekerjannya, maupun di lingkungan sosial masyarakatnya, seperti larangan berada di tempat-tempat yang dianggap dapat menurunkan martabat pegawai negeri sipil, kecuali dalam keadaan tugas khusus, seperti penyelidikan atau penyidikan.

Untuk mendisiplinkan kerja pegawai sebagai tindak lanjut dari peran dan fungsi pengawasan, maka terdapat tindakan-tindakan represif yang dilakukan oleh pemerintah daerah Provinsi Sulawesi Selatan, dalam hal ini pembina kepegawaian diantaranya.

\section{a. Sanksi administratif}

Sanksi administratif diberikan kepada para pegawai bilamana dalam monitoring dan evaluasi terhadap pegawai ditemukan adanya penyimpangan terhadap peraturan dan prosedur kerja, terutama yang berkaitan dengan hak dan kewajiban serta larangan bagi pegawai negeri sipil, sebagaimana diatur dalam Peraturan Pemerintah Nomor 53 Tahun 2010. Dengan kata lain jika perbuatan yang dilarang itu dilakukan oleh pegawai negeri sipil, maka pimpinan / atasannya berkewajiban melakukan tindakan sesuai dengan peraturan yang berlaku. 
Dari penelitian yang dilakukan penerapan sanksi administratif di atas, berdasarkan hasil penelitian yang dilakukan masih terlalu longgar, dalam arti bahwa pihak Badan Pendapatan Daerah Provinsi Sulawesi Selatan, belum secara maksimal menerapkan aturan sanksi tersebut.

\section{b. Sanksi Pidana dan Perdata}

Tindakan hukum adalah merupakan tindak lanjut dari pengawasan yang diambil, setelah hasil evaluasi menunjukkan bahwa pegawai yang bersangkutan melakukan pelanggaran hukuman berupa pelanggaran pidana atau perdata. Pelanggaran pidana dapat berupa penyalahgunaan keuangan negara/daerah (pidana korupsi) atau melakukan tindakan-tindakan pelanggaran hukum secara umum, seperti pelecehan seksual, penghinaan, pencurian, perampokan dan lain-lain sebagainya yang berkaitan dengan aspek pelanggaran hukum pidana sebagaimana diatur dengan KUHP. Sedangkan hukum perdata, adalah berkaitan dengan masalah persengketaan pegawai itu sendiri dengan kepentingan publik.

Periode tahun 2018 sampai dengan 2019, ternyata tidak dijumpai yang menyangkut tindak lanjut dari pengawasan, kecuali hanya hanya yang berkaitan dengan sanksi administratif kepada pegawai, itupun masih terbatas pada sanksi hukuman ringan berupa teguran lisan, teguran tertulis dan pernyataan tidak puas dari para atasan mereka.

Meskipun ada tingkat kesadaran aparatur yang cukup memadai dalam menjalankan tugas-tugasnya, namun perlu disadari pula bahwa prilaku dan karakter manusia, kadangkadang dapat dengan mudah berubah, dan sangat dipengaruhi oleh kondisi dan kesempatan yang ada di depan matanya, misalnya mungkin tidak ada niat untuk bolos kerja atau menyalahgunakan keuangan negara namun karena melihat ada kesempatan dan peluang yang terbuka, maka hal itupun dapat saja dilakukan. Di samping itu juga ada sebagian pegawai memerlukan pengawasan dan pengendalian dengan ketat, terutama pada pegawai dengan motivasi dan moril kerja yang rendah.

Pengawasan yang dilakukan terhadap penggunaan jam kerja oleh pegawai pada dasarnya merupakan kegiatan yang dilakukan secara terus menerus, bahkan dengan melalui apel setiap pagi serta absensi kerja baik pada jam masuk maupun jam keluar merupakan suatu langkah yang dimaksudkan untuk memonitoring para pegawai agar dapat melaksanakan tugas-tugasnya sebagaimana mestinya. Oleh sebab itu dapat dikatakan bahwa usaha-usaha untuk memantapkan peningkatan disiplin kerja pegawai, maka fungsi pengawasan yang dilakukan terutama melalui usaha-usaha preventif (apel pagi dan absensi) serta pengawasan oleh setiap atasan langsung serta pengawasan menyeluruh dalam penegakkan penggunaan jam kerja dan prosedur serta mekanisme kerja Badan Pendapatan Daerah Provinsi Sulawesi Selatan Provinsi Sulawesi Selatan.

Komitmen yang kuat untuk melaksanakan tugas-tugas dengan senang hati dengan tidak hanya bersandar pada aspek hak dan kewajiban semata, tentu akan memberikan dampak yang sangat luas pada penyelesaian tugas-tugas secara efektif. Adanya penyatuan (integrity) antara sikap kecintaan terhadap pekerjaan dan hak kewajiban serta tugas dan tanggung jawab selaku pegawai, yang ditujukan untuk mengabdikan diri pada masyarakat, bangsa dan negara merupakan cermin adanya keteguhan integritas pribadi seseorang dalam melaksanakan tugas-tugasnya. Dengan adanya integritas pribadi yang memadai dari pegawai jelas juga mencerminkan pada kemampuan untuk berinisiatif dalam menyelesaikan tugastugas dengan baik.

\section{KESIMPULAN}

Berdasarkan hasil penelitian yang dilakukan, maka dapat disimpulkan sebagai berikut :

a. Pengawasan preventif di Badan Pendapatan Daerah Provinsi Sulawesi Selatan dengan indicator pada disiplin kerja oleh pegawai, berjalan baik, yaitu umumnya menggunakan jam kerja sesuai ketentuan yang berlaku. Terdapat usahausaha yang cukup signifikan dari pegawai negeri untuk mentaati jam kerjanya. Oleh sebab hasil penelitian menunjukkan bahwa periode Tahun 2019/2020, sudah jarang sekali dijumpai adanya pegawai yang melanggar ketentuan mengenai jam kerja pegawai. Pengawasan preventif yang dilakukan struktur kepemimpinan dalam lingkup tugas Badan Pendapatan 
Daerah Provinsi Sulawesi Selatan, antara lain dilakukan melalui penerapan apel pagi dan apel jam pulang, terutama untuk memberikan apresiasi pada penggunaan jam kerja. Di samping itu telah disediakan instrumen penilaian kepada pegawai melalui penilaian absensi dengan mengaitkan penerimaan remonerasi berupa tunjangan uang makan yang dihitung berdasarkan kehadiran mereka dalam bekerja.

b. Tindakan pengawasan represif, maka berbagai tindakan yang dilakukan untuk mendisiplinkan pegawai dalam mentaati prosedur dan mekanisme kerja: Melakukan pemantauan pada pada ruangan kerja pegawai, mengecek penggunaan dan prosedur mekanisme kerja sesuai standar yang berlaku. Bila terdapat kasus-kasus yang dijumpai, maka tindakan represif yang dilakukan adalah meminta pegawai yang bersangkutan untuk menghadap langsung ke atasan, dan memberikan teguran peringatan dan bilamana itu belum ditaati, maka dilimpahkan ke pejabat Pembina kepegawaian melalui identifikasi masalah pada Badan Pendapatan Daerah Provinsi Sulawesi Selatan untuk melakukan evaluasi laporan disiplin pegawai.

\section{REFERENSI}

Gie, L. 1972. Kamus Administrasi. Gunung Agung. Jakarta.

Gibson, Ivancevich, Donnelly. 2006. Organisasi, Prilaku, Struktur dan Proses. Alih Bahasa Djakarsih, Erlangga, Jakarta.

Handayaningrat, Soewarno. 1992. Pengantar Studi Ilmu Administrasi dan Manajemen. Jakarta: CV Haji Masagung

Indrawijaya, E., Sitorus, B., \& Wacker, M. 1996. Fertigkeit Schreiben. Regionalfassung Indonesien.

Indrawidjaya. 2006. Kepemimpinan dan Motivasi. Liberty, Yogyakarta

Moenir, H. A. S. 2003. Pengembangan Sumber Daya Manusia. Pustaka, Jakarta.

Moenir, AS. 2001. Pendekatan Manusiawi dan Organisasi Terhadap Pembinaan Kepegawaian, Gunung Agung, Jakarta.
Murphy dan Cleveland. 2005. Sistem Managemen By Objective. Terjemahan Yanuar Irawan, LP3ES, Jakarta.

Sarwoto, A. 2003. Dasar-dasar Perilaku Organisasi (Cetakan Pertama). UII Press, Yogyakarta.

Sedarmayanti. 2001. Sumber Daya Manusia dan Produktivitas Kerja, Mandar Maju, Jakarta.

Siswanto, B. 2007. Produktivitas dan Penerapan. LSIUP1987.

Soekarno, K. 1986. Dasar-Dasar Manajemen.

LUSSA, G., \& F Soegeng Istanto, S. H. 2002. Pengawasan ketenagakerjaan dalam pelaksanaan program jaminan sosial tenaga kerja di Kabupaten Sleman (Doctoral dissertation, [Yogyakarta]: Universitas Gadjah Mada).

Sugiyono, S. 2010. Metode penelitian kuantitatif dan kualitatif dan $R \& D$.

Sugiyono. 2007. Metode Penelitian Administrasi. Alfabeta, Bandung.

Indonesia, P. R. 1999. Undang-Undang Republik Indonesia Nomor 28 Tahun 1999 Tentang Penyelenggaraan Negara yang Bersih dan Bebas Dari Korupsi, Kolusi, dan Nepotisme. 